\title{
Catfishes as prey items of Potamotrygonid stingrays in the Solimões and Negro rivers, Brazilian Amazon
}

\author{
Akemi Shibuya ${ }^{1,3}$ \& Jansen Zuanon ${ }^{2}$ \\ ${ }^{1}$ Departamento de Zoologia, Instituto de Biociências, Universidade de São Paulo - USP, \\ Rua do Matão, Trav. 14, 101, CEP 05508-090, São Paulo, SP, Brasil \\ ${ }^{2}$ Coordenação de Pesquisas em Biodiversidade, Instituto Nacional de Pesquisas da Amazônia - INPA, \\ Av. André Araújo, 2936, Aleixo, CEP 69060-001, Manaus, AM, Brasil \\ ${ }^{3}$ Corresponding author: Akemi Shibuya,e-mail:akemi_shibuya@yahoo.com.br
}

SHIBUYA, A. \& ZUANON, J. Catfishes as prey items of Potamotrygonid stingrays in the Solimões and Negro rivers, Brazilian Amazon. Biota Neotrop. 13(1): http://www.biotaneotropica.org.br/v13n1/en/abstract?shortcommunication+bn03213012013

Abstract: In spite of the fact that catfish have rarely been reported as food items in the diets of freshwater stingrays, they are commonly observed in the stomach contents of species inhabiting the Solimões and Negro rivers in the Brazilian Amazon. The stomach contents of six rays from the Solimões River and 64 from the Negro River were analyzed, and catfishes (distributed among the families Callichthyidae, Cetopsidae, Doradidae and Loricariidae) were found in the stomach contents of four and 10 of these rays, respectively, comprising a frequency of occurrence of $20 \%$. These data indicate a relevant participation of catfishes in the diets of potamotrygonid rays in the Amazon, and may reflect the regional diversity and abundance of Siluriformes in the region.

Keywords: diet, feeding, freshwater stingrays, Myliobatiformes, Siluriformes.

SHIBUYA, A. \& ZUANON, J. Os bagres como presas de raias Potamotrygonidae nos rios Solimões e Negro, Amazônia brasileira. Biota Neotrop. 13(1): http://www.biotaneotropica.org.br/v13n1/pt/abstract?shortcommunication+bn03213012013

Resumo: Apesar de ter sido reportado sobre a raridade de bagres na alimentação de raias de água doce, a presença deles tem sido comumente observada em conteúdos estomacais de espécies dos rios Solimões e Negro. Os conteúdos estomacais de seis indivíduos de raias do rio Solimões e 64 do rio Negro foram analisados e os bagres (distribuídos nas famílias Callichthyidae, Cetopsidae, Doradidae e Loricariidae) foram consumidos por quatro e 10 raias, respectivamente, com a frequência de ocorrência de $20 \%$. A ocorrência de Siluriformes, mesmo baixa, indica uma participação relevante deste grupo como presas na dieta dos potamotrigonídeos.

Palavras-chave: alimentação, dieta, raias de água doce, Myliobatiformes, Siluriformes. 


\section{Introduction}

Potamotrygonidae stingrays consume a wide variety of prey, feeding on insects, mollusks, crustaceans, and teleosteans (Lasso et al. 1996, Lonardoni et al. 2006, Rincon-Filho 2006, Silva \& Uieda 2007, Shibuya et al. 2009). Their diets may be directly related to the availability of any given prey, and some species display specific dietary habits [e.g. Potamotrygon orbignyi (Castelnau 1855) is considered predominantly insectivorous, whereas Paratrygon aiereba (Walbaum 1792) is mostly piscivorous] (Lasso et al. 1996, RinconFilho 2006, Shibuya et al. 2009). In spite of the low occurrence of fish in the diets of most potamotrygonid stingrays, some species are known for their considerable consumption of these prey items (e.g. Paratrygon aiereba). Specimens of Potamotrygon motoro (Müller \& Henle 1841) from the Middle Negro River in the Brazilian Amazon is known to consume principally crustaceans, although teleosteans also appear to be an important element in its diet (Lasso et al. 1996, Shibuya et al. 2009).

Silva \& Uieda (2007) reported that the two potamotrygonid species found in the Paraná River (Potamotrygon falkneri Castex \& Maciel 1963 and P. motoro) have diversified diets, and teleosteans were found in the stomach contents of just one specimen of each species. In addition to these observations, Garrone-Neto \& Uieda (2009) pointed out that the rare occurrences of catfishes (Siluriformes) in stingray diets may be considered occasional, as a consequence of inexperience and/or an accidental predation, since one of the analyzed specimens (a young individual of $P$. falkneri) had a dead catfish stuck in its oral chamber. However, Shibuya et al. (2009) described the diets of four species of Potamotrygonidae, and three of them (Potamotrygon sp. "cururu", P. motoro, and Paratrygon aiereba) were found to have different groups of catfishes (Callichthyidae, Cetopsidae, Doradidae and Loricariidae) in their stomachs. Almeida et al. (2010) and Vasconcelos \& Oliveira (2011) also found catfishes in the stomach of P. motoro, in the Marajó Island (which has connections with Amazonas and Tocantins Rivers) and in the Cariaú River (Amapá State), respectively.

Since catfishes compose more than $40 \%$ of the Amazon fish species richness, it would be surprising to find that they not compose common prey items in the diets of stingrays. Moreover, many catfish species of different families, with varied morphologies and sizes, share the shallow margins of the rivers inhabited by stingrays. The present study aims to demonstrate that Siluriformes should be considered normal prey items of potamotrygonid stingrays inhabiting the Solimões and Negro rivers in the Brazilian Amazon, and arguing that catfish's spines and body armor do not constitute barriers to its consumption by the rays.

\section{Materials and Methods}

Stingray sampling is strongly seasonal, with an inverse relationship between capture vulnerability and water level in the river (see Araújo 1998). In this sense, most of the information available on the diet of stingrays refers to the dry season; the few studies that present dietary data for stingrays during the flood season were Almeida et al. (2010) and Vasconcelos \& Oliveira (2011), both developed in the lower portion of the Amazon basin where the seasonal changes in river level are attenuated by the daily tidal variations. The data set analyzed in this study was composed by a combination of newly collected samples (from Solimões River), and by samples previously obtained in Negro River (Shibuya et al. 2009). Both sampling areas are part of the Amazon lowlands and are subjected to a strong seasonal flood pulse (Junk et al. 1989), with flood peak in June-July and the lowest water level in SeptemberOctober. The main difference between the sampling areas is related to water type and biological productivity. Solimões River drains a wide várzea floodplain of turbid waters with a nearly neutral $\mathrm{pH}$ and high productivity, with a high biomass of plants and fishes mainly concentrated in seasonally available lakes; on the other hand, the black waters of Negro River are acidic and nutrient poor, and sustain a comparatively much lower biomass (Junk 1984).

Specimens of Paratrygon aiereba $(\mathrm{n}=2)$ and Plesiotrygon iwamae Rosa, Castello \& Thorson $1987(\mathrm{n}=6)$ were collected in November/2011 in the Lower Solimões River ( $03^{\circ} 17^{\prime} 54$ ' $\mathrm{S}$ and $60^{\circ}$ 03'03” W) in the municipality of Careiro da Várzea, Amazonas State, Brazil. All specimens were collected using trammel nets $(50 \mathrm{~m}$ and $100 \mathrm{~m}$ length, with $40 \mathrm{~mm}$ mesh size $)$ and bottom trotlines $(200 \mathrm{~m}$ length, with 200 hooks) by local fishermen during the night, in shallow margins and beaches along the river channel. The rays were euthanized using Eugenol (clove oil) and identified according to Rosa (1985). The stomachs of these animals were removed and fixed in $10 \%$ formalin solution. Stomach contents were analyzed with the aid of a stereoscopic microscope. Prey items were sorted and subsequently counted and maintained in $70 \%$ ethanol solution. Catfishes found in the stomach contents were identified to the lowest taxonomic level possible with the aid of identification keys (e.g. Burgess 1989) and the help of specialists. Data concerning Potamotrygon motoro $(\mathrm{n}=32), P$. sp. "cururu" $(\mathrm{n}=17)$, and Paratrygon aiereba $(\mathrm{n}=15)$, all collected in the Middle Negro River near Barcelos (Amazonas State, Brazil) have recently been published by Shibuya et al. (2009), and that information was updated in reference to the occurrence of Siluriformes. The gut contents analyzes and catfish identification were done by the same persons, in order to allow an accurate comparison of both datasets. Results are presented as frequency of occurrence values (i.e. the number of stomachs containing catfish remains, in relation to the total number of the analyzed stomachs that contained food), and as numerical frequency (number of catfish specimens consumed in relation to the total number of fish ingested by the rays) (Hyslop 1980).

\section{Results and Discussion}

Among the eight stingray specimens analyzed from the Solimões River (two Paratrygon aiereba and six Plesiotrygon iwamae), one individual of $P$. aiereba $(31 \mathrm{~cm}$ disc width) and three of $P$. iwamae (ranging from 51.5 to $64.0 \mathrm{~cm}$ disc width) had remains of thorny catfishes (Doradidae) in their stomachs; two stomachs were empty. In addition, $P$. iwamae had also consumed freshwater shrimps (Table 1). The Frequency of Occurrence of catfishes in the stomachs of these six specimens was $50.0 \%$, and the Numerical Frequency of catfishes in relation to other prey fish was $44.4 \%$ (Table 2 ).

Potamotrygon motoro $(\mathrm{n}=1), P$. sp. "cururu" $(\mathrm{n}=5)$, and Paratrygon aiereba $(\mathrm{n}=4)$ from the Negro River had ingested fish from four different Siluriformes families: Callichthyidae,

Table 1. Prey items found in the stomachs of Paratrygon aiereba and Plesiotrygon iwamae, from Solimões River, expressed in number $(\mathrm{N})$ and occurrence (O). Numbers of obtained specimens (n), stomachs with contents (c) and empty stomachs (e) are presented for each potamotrygonid species.

\begin{tabular}{|c|c|c|c|c|}
\hline \multirow[t]{2}{*}{ ITEMS } & \multicolumn{2}{|c|}{$\begin{array}{c}\text { Paratrygon } \\
\text { aiereba } \\
(\mathrm{n}=2 ; \mathrm{c}=1 ; \mathrm{e}=1)\end{array}$} & \multicolumn{2}{|c|}{$\begin{array}{c}\text { Plesiotrygon } \\
\text { iwamae } \\
(\mathrm{n}=6 ; \mathrm{c}=5 ; \mathrm{e}=1)\end{array}$} \\
\hline & $\mathbf{N}$ & $\mathbf{O}$ & $\mathbf{N}$ & $\mathbf{O}$ \\
\hline Doradidae & 1 & 1 & 2 & 2 \\
\hline Hemiodontidae & 1 & 1 & 1 & 1 \\
\hline Cichlidae & - & - & 3 & 1 \\
\hline Unidentified catfishes & - & - & 1 & 1 \\
\hline Shrimps & - & - & 2 & 2 \\
\hline
\end{tabular}


Shibuya, A. \& Zuanon, J.

Table 2. Total values of the stomachs with contents (N) in potamotrygonid stingrays from Solimões and Negro Rivers. The number of stomachs with catfish and total of fish prey and catfish prey in the analyzed stomachs are expressed in number $(\mathrm{N})$ and frequency of occurrence $(\%)$.

\begin{tabular}{lcccc}
\hline \multirow{2}{*}{ River } & Stomach with food & Stomach with catfish & Total fish prey & \multicolumn{2}{c}{ Total catfish prey } \\
& $\mathbf{N}$ & $\mathbf{N}(\mathbf{\%})$ & $\mathbf{N}$ & $\mathbf{N}(\mathbf{\%})$ \\
\hline Solimões & 6 & $3(50.0)$ & 9 & $4(44.4)$ \\
Negro & 64 & $10(15.6)$ & 114 & $15(13.1)$ \\
\hline
\end{tabular}

Loricariidae, Doradidae and Cetopsidae (see Shibuya et al. 2009 for details on additional prey items consumed). All catfishes found in the stomach contents of Paratrygon aiereba and Plesiotrygon iwamae from the Solimões River measured about $4-8 \mathrm{~cm}$ of total length. Most of catfishes found in the stomachs of stingrays from Negro River reached $8 \mathrm{~cm}$, except one Cetopsidae found in the stomach of a specimen of Paratrygon aiereba, which was about $25 \mathrm{~cm}$ total length. Among the Negro River specimens, the Frequency of Occurrence of catfishes in the stomachs was $15.6 \%$, and the Numerical Frequency of catfishes in relation to other prey fish was $13.1 \%$. Overall (Solimões and Negro rivers pooled), catfishes were found in 14 of the 70 stingrays with food in their stomachs, comprising a Frequency of Occurrence of $20.0 \%$, and a Numerical Frequency of $15.4 \%$ (Table 2).

Similar to the Heptapteridae prey found by Garrone-Neto \& Uieda (2009) in the diet of Potamotrygon falkneri, catfishes of Doradidae, Callichthyidae, and Loricariidae have spines on their pectoral and dorsal fins that serve as defense mechanisms - although not pungent in the case of loricariids (Bosher et al. 2006, Kirchheim \& Goulart 2010). Some doradid catfishes also have a row of bony plates along the sides of the body, each plate armed with a sharp spine or hook that can inflict injuries to its potential predators (q.v. Burgess 1989). Despite these supposed obstacles to its ingestion, the catfishes consumed by the potamotrygonid stingrays from the Solimões and Negro Rivers were found crushed and in an advanced state of digestion. These catfish species are quite common in the rivers where the stingrays were collected, and live predominantly associated with the substrate where stingrays forage (Lowe McConnell 1987, J. Zuanon, personal observation along the whole Solimões-Amazonas River and Lower Negro River, since 1987). It is possible that the differential availability of catfish in the Paraná River basin influences their infrequent consumption by the stingrays locally, and may be responsible for the observed differences between the diets of potamotrygonid populations in the Amazon River basins and in the Paraná River. Therefore, additional studies comparing stingrays diets and catfish prey availability in Paraná River basin could be elucidative.

Potamotrygon motoro from the Negro River has a muscular orobranchial system adapted to breaking rigid structures of hard prey (Shibuya et al. 2012), which may explain the crushed condition of doradid and loricariid preys found in the stomach contents of the analyzed specimens. The catfishes consumed by Paratrygon aiereba were found intact within their stomachs, which could indicate its ingestion by suction mechanisms. One specimen of Plesiotrygon iwamae had a catfish spine lodged in its stomach wall, indicating that such injuries may not impair the consumption of this kind of prey.

An alternative hypothesis for the findings presented by GarroneNeto \& Uieda (2009) is that the presence of a catfish locked in the oral cavity of an individual of P. falkneri may have resulted from a poorly succeeded capture attempt by that individual ray. The catfish's immediate attempt to escape predation after being engulfed may have lead it to become stuck and protruding from the spiracular aperture of the stingray, as found by those authors. However, this accident does not imply that catfishes are necessarily infrequent preys of stingrays. In addition to the presence of Siluriformes in the stomach contents of stingrays in the Amazon Basin, another fact that reinforces its importance as stingray preys is the frequent finding of broken catfish spines deeply inserted in the musculature around the oral region of stingrays utilized for human consumption (J. Zuanon, personal observation), which indicates the common occurrence of predation attempts on catfishes.

Freshwater stingrays do not necessarily have similar feeding habits in different hydrographic basins. Potamotrygon motoro seems to be predominantly insectivorous in the Cristalino (a tributary of the Araguaia River) and Paraná rivers (Pantano-Neto 2001, Lonardoni et al. 2006, Silva \& Uieda 2007), while individuals inhabiting the Negro River take crustaceans as their most important prey, followed by teleosteans (Shibuya et al. 2009). In addition, Almeida et al. (2010) and Vasconcelos \& Oliveira (2011) also showed the occurrence of teleosteans, including catfishes, in the diet of potamotrygonid stingrays. Any generalization of the feeding habits of ray species derived from studies carried out in a single population may be misleading.

One aspect of the trophic ecology of stingrays that remains to be studied is the possible seasonal variation in the diet of these species in the Amazon lowlands. Vasconcelos \& Oliveira (2011) stated that food consumption was different between the rainy and dry seasons for $P$. motoro, with higher consumption of mollusks during the flood. Although Almeida et al. (2010) had collected P. motoro during dry, rainy and transitional seasons, but they did not test for statistical differences in its diet among seasons. Seasonal differences on the feeding habits of fishes that occupy the seasonally available flooded forests and floodplains are well known for several fish groups (e.g. Goulding 1980, Claro-Junior et al. 2004, Yamamoto et al. 2004), and there is no reason to suppose that stingrays species do not change diets along the seasonal cycle; however, it would be necessary to have a much more intensive collecting effort during rising and flood periods to test this hypothesis, in function of the difficulties to obtain enough samples to analyze.

\section{Acknowledgements}

The authors would like to thank W. Duncan, F. C. Valentim, and M. L. Araújo for supplying the stomach contents of the stingrays; R. R. Oliveira for discussions concerning the biology of catfishes. AS thanks the Fundação de Amparo à Pesquisa do Estado de São Paulo (FAPESP - grant no. 2011/23683-0). JZ receives a productivity grant from CNPq (307464/2009-1).

\section{References}

ARAÚJO, M.L.G. 1998. Biologia de Potamotrygon sp. C (Chondrichthyes: Potamotrygonidae) no médio rio Negro, Amazonas. Unpublished Master dissertation. FUA/INPA, Manaus, 171p.

ALMEIDA, M.P., LINS, P.M.O., CHARVET-ALMEIDA, P. \& BARTHEM, R.B. 2010. Diet of the freshwater stingray Potamotrygon motoro (Chondrichthyes: Potamotrygonidae) on Marajó Island (Pará, Brazil). Braz. J. Biol. 70(1):155-162. http://dx.doi.org/10.1590/S151969842010000100022 
BOSHER, B.T., NEWTON, S.H. \& FINE, M.L. 2006. The spines of the channel catfish, Ictalurus punctatus, as an anti-predator adaptation: an experimental study. Ethology. 112(2006):188-195. http://dx.doi. org/10.1111/j.1439-0310.2006.01146.x

BURGESS, W.E. 1989. An atlas of freshwater and marine catfishes: a preliminary survey of the Siluriformes. Tropical Fish Hobbyist Publications, Inc., Neptune City.

CLARO-JUNIOR, L., FERREIRA, E., ZUANON, J. \& ARAÚJO-LIMA, C. 2004. O efeito da floresta alagada na alimentação de três espécies de peixes onívoros em lagos de várzea da Amazônia Central, Brasil. Acta Amazon. 34(1):133-137. http://dx.doi.org/10.1590/S004459672004000100018

GARRONE-NETO, D. \& UIEDA, V.S. 2009. Ingestion of catfish by freshwater stingray: possible mistake or inexperience. Biota Neotrop. 9 (4): http://www.biotaneotropica.org.br/v9n4/en/abstract? shortcommun ication+bn01609042009.

GOULDING, M. 1980. The fishes and the forest: Explorations in Amazonian Natural History. University of California Press, Berkeley, California, 280p.

HYSLOP, E.J. 1980. Stomach contents analysis review of methods and their applications. J. Fish Biol. 17:411-429. http://dx.doi. org/10.1111/j.1095-8649.1980.tb02775.x

JUNK, W.J. 1984. Ecology, fisheries and fish culture in Amazonia. In The Amazon, Limnology and landscape ecology of a mighty tropical fiver and its basin (H. Sioli, ed.). Dr. W. Junk, Dordrecht, p.443-476.

JUNK, W.J., BAYLEY, P.B. \& SPARKS, R.E. 1989. The flood pulse concept in river-floodplain systems. Canadian J. Fish. Aquat. 106:110-127.

KIRCHHEIM, P.D. \& GOULART, E. 2010. Ecomorfologia de predação e antipredação em Siluriformes (Osteichthyes). Oecol. Austral. 14(2): 550568. http://dx.doi.org/10.4257/oeco.2010.1402.12

LASSO, C.A., RIAL, A.B. \& LASSO-ALCALÁ, O. 1996. Notes on the biology of the freshwater stingrays Paratrygon aiereba (Müller and Henle, 1841) and Potamotrygon orbignyi (Castelnau, 1855) (Chondrichthyes: Potamotrygonidae) in the Venezuelan llanos. Aqua J. Ichth. and Aquat. Biol. 2(3):39-52.
LONARDONI, A.P., GOULART, E., OLIVEIRA, E.F. \& ABELHA, M.C.F. 2006. Hábitos alimentares e sobreposição trófica das raias Potamotrygon falkneri e Potamotrygon motoro (Chondrichthyes, Potamotrygonidae) na planície alagável do alto rio Paraná, Brasil. Acta Scient. Biol. Sci. 3(28):195-202.

LOWE-McCONNELL, R.H. 1987. Ecological studies in tropical fish communities. Cambridge University Press, Cambridge, 382p. http:// dx.doi.org/10.1017/CBO9780511721892

PANTANO-NETO, J. 2001. Estudo preliminar da anatomia descritiva e funcional associada à alimentação em raias de água-doce (Potamotrygonidae, Myliobatiformes, Elasmobranchii). Dissertação de mestrado, Universidade de São Paulo, São Paulo, 92p.

RINCON-FILHO, G. 2006. Aspectos taxonômicos, alimentação e reprodução da raia de água doce Potamotrygon orbignyi (Castelnau) (Elasmobranchii: Potamotrygonidae) no Rio Paranã-Tocantins. Tese de doutorado, Universidade Estadual Paulista "Júlio Mesquita Filho", Rio Claro, 132p.

ROSA, R.S. 1985. A systematic revision of the South American freshwater stingrays (Chondrichthyes: Potamotrygonidae). PhD. Thesis, College of William and Mary, Virginia, 523p.

SHIBUYA, A., ARAÚJO, M.L.G. \& ZUANON, J.A.S. 2009. Analysis of stomach contents of freshwater stingrays (Elasmobranchii: Potamotrygonidae) from the middle Negro River, Amazonas, Brazil. Pan-American J. Aqua. Sci. 4(4):466-465.

SHIBUYA, A. ZUANON, J. \& TANAKA, S. 2012. Feeding behavior of the Neotropical freshwater stingray Potamotrygon motoro (Elasmobranchii: Potamotrygonidae). Neot. Ichth. 10(1):189-196. http://dx.doi. org/10.1590/S1679-62252012000100018

SILVA, T.B. \& UIEDA, V.S. 2007. Preliminary data on the feeding habits of the freshwater stingrays Potamotrygon falkneri and Potamotrygon motoro (Potamotrygonidae) from the Upper Paraná River basin, Brazil. Neotrop. 7(1):221-226.

VASCONCELOS, H.C.G. \& OLIVEIRA, J.C.S. 2011. Alimentação de Potamotrygon motoro (Chondrichthyes, Potamotrygonidae) na planície de inundação da APA do rio Curiaú, Macapá - Amapá - Brasil. Biota Amazôn. 1(2):66-73.

YAMAMOTO, K.C., SOARES, M.G.M. \& FREITAS, C.E.C. 2004 Alimentação de Triportheus angulatus (Spix \& Agassiz, 1829) no lago Camaleão, Manaus, AM, Brasil. Acta Amazon. 34(4):653-659. http:// dx.doi.org/10.1590/S0044-59672004000400017 